\title{
The Effect of Medium Redox Potential on the Folate-limited Growth of Lactobacillus casei var. rhamnosus
}

\author{
By G. B. TENNANT \\ Department of Haematology, Welsh National School of Medicine, \\ Heath Park, Cardiff $\mathrm{CF}_{4} 4 \mathrm{XW}$
}

(Received I5 April 1975; revised 8 July 1975)

SUMMARY

The medium redox potential $\left(E_{\mathrm{h}}\right)$ influenced the folate-limited growth of Lactobacillus casei; the growth response was maximal at an $E_{\mathrm{h}}$ of $+120 \mathrm{mV}$ (pH 6.35). At raised $E_{\mathrm{h}}$ serum folate would support less growth than pteroylglutamic acid, and the response to $N^{5}$-methyl tetrahydrofolic acid was intermediate between them. Pteroylglutamic acid was not destroyed during $24 \mathrm{~h}$ incubation at $37^{\circ} \mathrm{C}$ in medium with $E_{\mathrm{h}}$ values between +40 and $+440 \mathrm{mV}$. Destruction of $N^{5}$-methyl tetrahydrofolic acid occurred within $24 \mathrm{~h}$ when the medium $E_{\mathrm{b}}$ was greater than $+125 \mathrm{mV}$. Folate was taken up rapidly by $L$. casei with an $E_{\mathrm{h}}$ optimum at $+270 \mathrm{mV}$.

\section{INTRODUCTION}

Ascorbic acid has been used to prevent oxidation of the folate activity of serum during assay procedures using Lactobacillus casei, since the work of Toennies, Frank \& Gallant (1953). Herbert (196I) noted that ascorbic acid stimulates the growth of $L$. casei cultures containing pteroylglutamic acid (PteGlu) as folate source. Whole serum assay techniques using aseptic addition of serum (Herbert, 1966) or chloramphenicol-resistant strains of L. casei (Davis, Nichol \& Kelly, 1970) have eliminated the oxidation problems associated with the extraction of folate activity. Published methods of folate assay with chloramphenicol-resistant strains of $L$. case $i$ use ascorbate concentrations in the assay medium ranging from $0.05 \mathrm{~g} / 1$ (O'Broin, Scott \& Temperley, 1973) to $\mathrm{I} \cdot 0 \mathrm{~g} / \mathrm{l}$ (Chanarin, Kyle \& Stacey, 1972; Scott, Ghanta \& Herbert, 1974). The present work seeks to define the effect of ascorbate on the medium redox potential $\left(E_{\mathrm{h}}\right)$ and relate this to the growth response of L. casei to folate.

\section{METHODS}

Redox control. A range of medium $E_{\mathrm{h}}$ values was obtained by adding hydrogen peroxide [' 20 volume' (i.e. $6 \%$, w/v) $\mathrm{H}_{2} \mathrm{O}_{2}$ in water] to the medium at $0.8 \mathrm{ml} / \mathrm{l}$, together with doubling dilutions of a reducing agent. Sodium ascorbate was used in most experiments, over a concentration range of 0.025 to $25 \mathrm{~g} / \mathrm{l}$. Other reducing agents used were sodium erythorbate (sodium D-iso-ascorbate), over the range 0.5 to $50 \mathrm{~g} / \mathrm{l}$, and sodium thioglycollate, over the range 1.56 to $50 \mathrm{~g} / \mathrm{l}$.)

Measurement of redox potential. This was done with a Vibron $39 \mathrm{~A} \mathrm{pH}$ meter (Electronic Instruments Ltd, Chertsey, Surrey) using a platinum electrode and a calomel reference cell with a saturated $\mathrm{KCl}$ salt bridge. The correction voltage was $+242 \mathrm{mV}$ at $25^{\circ} \mathrm{C}$ (Glasstone, 1956). The $E_{\mathrm{h}}$ measurements were made on uninoculated blanks which had been left at room temperature to equilibrate for $\mathrm{I} \cdot 5$ to $2 \mathrm{~h}$.

Organisms. Several strains of Lactobacillus casei var. rhamnosus were used (ATcC7469, 
CRI, NCDO243, NCIB6375, NCIB8010, NCIBIO463 and NCTCI0302). The relationships of these strains to one another have been noted previously (Tennant et al. 1974), together with details of the maintenance procedures. All the strains were obtained as, or were made, chloramphenicol-resistant. Inoculum cultures were grown overnight at $37^{\circ} \mathrm{C}$ in $10 \mathrm{ml}$ volumes of assay medium containing PteGlu $(250 \mathrm{ng} / \mathrm{l})$ and chloramphenicol $(20 \mathrm{mg} / \mathrm{l})$. Organisms were not washed before use as the growth was folate-limited.

Culture procedure. The conditions under which cultures were grown were based on the serum folate assay procedure of Tennant \& Withey (1972). They were similar to those described previously (Tennant $e$ t al. 1974 ) except that the phosphate buffer concentration in the assay medium was decreased to $0.075 \mathrm{M}$. The $\mathrm{pH}$ of the assay medium was $6 \cdot 35$.

Folate source. PteGlu (Sigma) solutions of $5.5 \mu \mathrm{g} / 1$ were freshly prepared from $\mathrm{I} \mathrm{g} / \mathrm{l}$ stock solutions stored at $-20^{\circ} \mathrm{C}$. DL- $N^{5}$-methyl tetrahydrofolic' acid $\left({ }_{5} \mathrm{CH}_{3} \mathrm{H}_{4} \mathrm{PteGlu}\right.$; Sigma) was found to be about half as effective as PteGlu in supporting the growth of $L$. casei. Working solutions of I I $\mu \mathrm{g} / \mathrm{l}$ were used. Sera with folate concentrations between 5.0 and $6.0 \mu \mathrm{g} / \mathrm{l}$ were pooled. Folate sources were diluted $\mathrm{I} / 40$ into the culture medium.

Oxidative destruction of folate. PteGlu $(50 \mu \mathrm{g} / \mathrm{l})$ and ${ }_{5} \mathrm{CH}_{3} \mathrm{H}_{4}$ PteGlu $(100 \mu \mathrm{g} / \mathrm{l})$ were incubated at $37^{\circ} \mathrm{C}$ for $24 \mathrm{~h}$ in uninoculated medium at a range of $E_{\mathrm{h}}$ values. The folate remaining was assayed after diluting $\mathrm{I} / \mathrm{10}$ in $0.2 \%(\mathrm{w} / \mathrm{v})$ sodium ascorbate solution. The resultant $E_{\mathrm{h}}$ was $+140 \mathrm{mV}$ (pH 6.55) regardless of the $E_{\mathrm{h}}$ of the medium incubated.

Uptake of folate by $L$. casei. The rate of PteGlu uptake was measured by resuspending bacteria from overnight cultures in double strength assay medium $\left(E_{560 \mathrm{~mm}}^{1 \mathrm{~cm}}=0.03\right)$. Samples were diluted with equal volumes of PteGlu solution (10 $\mu \mathrm{g} / 1)$ and incubated in centrifuge tubes at $37^{\circ} \mathrm{C}$. Tubes were withdrawn at intervals and the organisms sedimented. The supernatant folate was assayed.

The effect of medium $E_{\mathrm{h}}$ on the uptake of PteGlu was measured similarly. Bacteria were resuspended in four times strength medium and equal volumes of PteGlu, hydrogen peroxide and sodium ascorbate solutions added. Incubation was for $15 \mathrm{~min}$.

\section{RESULTS}

\section{Control of medium $E_{\mathrm{h}}$}

The $E_{\mathrm{h}}$ value of folate assay medium without redox control varied from day to day within the range +150 to $+220 \mathrm{mV}$. The effect of adding ascorbate is shown in Fig. I. An extended $E_{\mathrm{h}}$ range of about +40 to $+440 \mathrm{mV}$ was obtained by adding reducing agent to medium containing hydrogen peroxide. None of the strains showed any catalase-like activity when hydrogen peroxide was added to dense concentrations of the bacteria (Whittenbury, 1964).

\section{Effect of medium $E_{\mathrm{h}}$ on the growth response to folate}

Comparison of the growth response of $L$. casei ( $\mathrm{NCIB6375)}$ to $\mathrm{PteGlu},{ }_{5} \mathrm{CH}_{3} \mathrm{H}_{4} \mathrm{PteGlu}$ and serum folate over a medium $E_{\mathrm{n}}$ range of +40 to $+440 \mathrm{mV}$ is shown in Fig. 2. The curves are the mean results of four experiments. Results fitted the same curves when ascorbate was added to medium without hydrogen peroxide, although the $E_{\mathrm{b}}$ values were obtained with different concentrations of ascorbate. The use of sodium erythorbate and sodium thioglycollate as reducing agents also gave similar curves.

Twenty sera with folate values between 2.0 and $9.0 \mu \mathrm{g} / 1$ were used individually as folate sources and 16 showed identical percentage growth responses to changing $E_{\mathrm{h}}$, regardless of serum folate value. The growth responses of these 16 sera showed greater sensitivity to raised $E_{\mathrm{h}}$ values than was found with ${ }_{5} \mathrm{CH}_{3} \mathrm{H}_{4} \mathrm{PteGlu}$ as folate source. Three other sera 


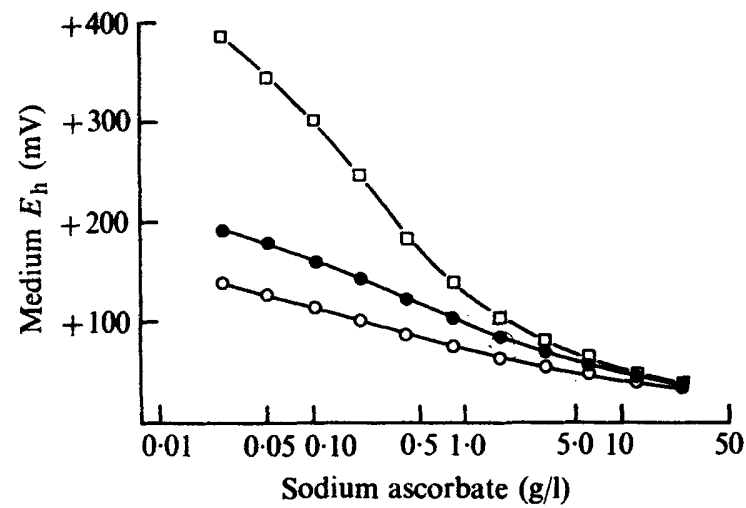

Fig. I

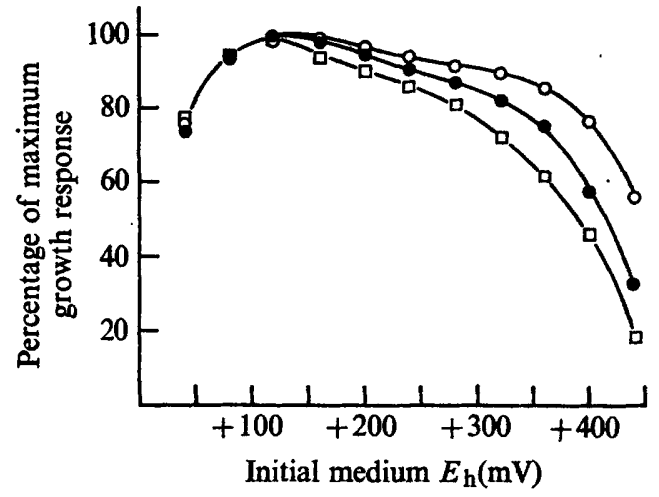

Fig. 2

Fig. 1. Effect of sodium ascorbate concentration on the redox potential of assay medium (pH 6.35). $O$, Not boiled; $O$, boiled; $\square$, plus hydrogen peroxide.

Fig. 2. Effect of redox potential on the growth of $L$. casei NcIB6375 limited by PteGlu (O), ${ }_{5} \mathrm{CH}_{3} \mathrm{H}_{4}$ PteGlu (O), and serum folate ( $\square$ ).

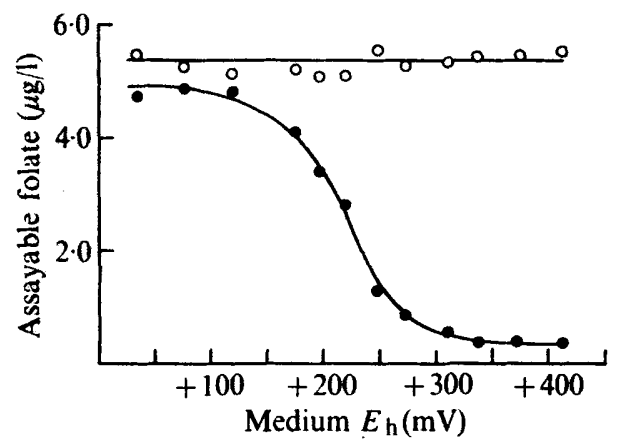

Fig. 3

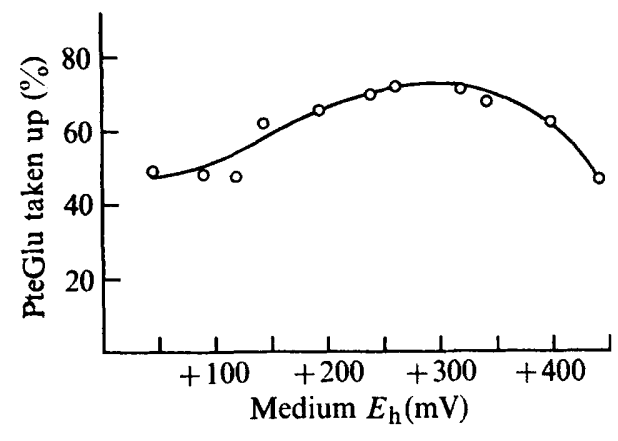

Fig. 4

Fig. 3. Effect of redox potential on the stability of PteGlu $(O)$ and $5 \mathrm{CH}_{3} \mathrm{H}_{4} \mathrm{PteGlu}(\mathrm{O})$ during $24 \mathrm{~h}$ incubation at $37^{\circ} \mathrm{C}$.

Fig. 4. Effect of redox potential on the uptake of PteGlu by NCIB6375 during 15 min incubation at $37^{\circ} \mathrm{C}$.

showed responses similar to ${ }_{5} \mathrm{CH}_{3} \mathrm{H}_{4} \mathrm{PteGlu}$ and one was intermediate between ${ }_{5} \mathrm{CH}_{3} \mathrm{H}_{4}$ PteGlu and PteGlu.

When excess PteGlu ( $\mathrm{I} \mathrm{mg} / \mathrm{l}$ ) was added to the culture medium the growth response was not affected by medium $E_{\mathrm{b}}$ over the range +35 to $+420 \mathrm{mV}$.

All the strains derived from ATCC7469 (i.e. ATCC7469, CRI, NCD0243, NCIB6375, NCIB8010 and NCIBI0463) showed a maximum growth response at an $E_{\mathrm{h}}$ of $+120 \mathrm{mV}$, regardless of the folate source. In contrast $\mathrm{NCTC} 10302$ showed a maximum growth response at $+90 \mathrm{mV}$. When compared with the other strains, ATCC 7469 showed a lower growth response to all forms of folate at $E_{\mathrm{h}}$ values greater than $+120 \mathrm{mV}$. The growth response below $+120 \mathrm{mV}$ was similar to the other strains.

\section{Oxidative destruction of folate}

${ }_{5} \mathrm{CH}_{3} \mathrm{H}_{4}$ PteGlu was stable during $24 \mathrm{~h}$ incubation at $E_{\mathrm{h}}$ values below $+125 \mathrm{mV}$, but it was destroyed at higher values (Fig. 3). There was no destruction of PteGlu under these 
conditions. The rate of destruction of ${ }_{5} \mathrm{CH}_{3} \mathrm{H}_{4} \mathrm{PteGlu}$ was measured in medium with an $E_{\mathrm{h}}$ of $+48 \mathrm{I} \mathrm{mV}$. Loss of assayable folate was detectable after less than $15 \mathrm{~min}$ incubation. About $25 \%$ of the activity was lost after $2 \mathrm{~h}$ incubation, and after $24 \mathrm{~h}$ only $5 \%$ remained.

\section{Uptake of folate by L. casei}

The rate of uptake of PteGlu was estimated in medium with a ratio of $L$. casei organisms to folate concentration similar to a mid-curve standard at inoculation of a routine assay, but with the concentrations of organisms and PteGlu both increased 40-fold. The rate of uptake varied from strain to strain; NCIB6375 removed about $50 \%$ of the PteGlu from the medium in 10 to $15 \mathrm{~min}$.

The effect of medium $E_{\mathrm{h}}$ on the uptake of PteGlu by NCIB6375 was measured over a I5 min period so that changes in growth response related to $E_{\mathrm{h}}$ should not influence the results. Maximum uptake was shown when the medium $E_{\mathrm{n}}$ was between +220 and $+340 \mathrm{mV}$ (Fig. 4).

\section{DISCUSSION}

Folate-limited growth of $L$. case $i$ showed an optimum response at $+120 \mathrm{mV}$; this was not a reflexion of oxidative destruction of folate, as PteGlu was stable in medium at the $E_{\mathrm{h}}$ values studied. The growth response to serum folate was lower than to PteGlu at $E_{\mathrm{h}}$ values above $+125 \mathrm{mV}$ and this was probably due to oxidation of the serum folate. The folate activity of serum has been shown to be due to ${ }_{5} \mathrm{CH}_{3} \mathrm{H}_{4}$ PteGlu (Herbert, Larrabee \& Buchanan, 1962) and the lower growth occurred at $E_{\mathrm{h}}$ values where ${ }_{5} \mathrm{CH}_{3} \mathrm{H}_{4} \mathrm{PteGlu}$ was destroyed. The difference in growth response was relatively small because the rapid uptake of folate into the bacteria allows minimal time for the destruction of serum folate. Approximately half the serum folate activity in healthy subjects is protein bound (Markkanen et al. 1973). This may slow the rate of uptake into bacteria (Waxman, 1975) and thereby result in an apparently greater lability of serum folate than ${ }_{5} \mathrm{CH}_{3} \mathrm{H}_{4}$ PteGlu. Markkanen et al. (1973) reported a wide range of percentage binding in a variety of clinical situations. These included some sera with no apparent binding, which may explain the behaviour of those samples where $E_{\mathrm{h}}$ sensitivity was similar to that with ${ }_{5} \mathrm{CH}_{3} \mathrm{H}_{4} \mathrm{PteGlu}$.

The effect of medium $E_{\mathrm{h}}$ on the folate-limited growth response seems to find expression in the uptake and utilization of folate by the cell. The growth response of cultures containing excess PteGlu were not affected by changes in the medium $E_{\mathrm{b}}$. Folate is taken up into $L$. casei by an active transport mechanism (Wood $\&$ Hitchings, 1959) which has an $E_{\mathrm{h}}$ optimum at $+270 \mathrm{mV}$. Comparison of Figs. 2 and 4 shows that the effect of medium $E_{\mathrm{h}}$ on the PteGlu uptake is probably the main factor in changes in the growth response at $E_{\mathrm{h}}$ values greater than about $+300 \mathrm{mV}$.

In the whole serum assay of folate a medium $E_{\mathrm{h}}$ between +90 and $+150 \mathrm{mV}(\mathrm{pH} \mathrm{6.35)}$ would maintain an optimum growth response which is independent of the form in which folate is provided. Under our conditions of assay the addition of sodium ascorbate to the medium at a concentration of $0.1 \mathrm{~g} / 1(0.5 \mathrm{~g} / \mathrm{l}$ if the medium is boiled) would achieve this (Fig. I). 


\section{REFERENCES}

Chanarin, I., Kyle, R. \& Stacey, J. (1972). Experience with microbiological assay for folate using a chloramphenicol-resistant $L$. casei strain. Journal of Clinical Pathology 25, 1050-1052.

Davis, R. E., Nichol, D. J. \& Kelly, A. (1970). An automated method for the measurement of folate activity. Journal of Clinical Pathology 23, 47-53.

Glasstone, S. (1956). Textbook of Physical Chemistry, 2nd edn, p. 941. London: Macmillan.

Herbert, V. (1961). The assay and nature of folic acid activity in human serum. Journal of Clinical Investigation 40, 81-92.

Herbert, V. (1966). Aseptic addition method for Lactobacillus casei assay of folate activity in human serum. Journal of Clinical Pathology 19, $12-16$.

Herbert, V., Larrabee, A. R. \& Buchanan, J. M. (1962). Studies on the identification of a folate compound of human serum. Journal of Clinical Investigation 41, $1134-1138$.

Markkanen, T., Pajula, R. L.. Himanen, P. \& Virtanen, S. (1973). Serum folic acid activity (L. casei) in Sephadex gel chromatography. Journal of Clinical Pathology 26, 486-493.

O’Bron, J. D., Scotr, J. M. \& Temperley, I. J. (1973). A comparison of serum folate estimations using two different methods. Journal of Clinical Pathology 26, 80-8I.

Scott, J. M., Ghanta, V. \& HerberT, V. (1974). Trouble-free microbiologic serum and red cell folate assays. American Journal of Medical Technology 40, 125-134.

Tennant, G. B., Newberry, C. H., Davies, J. \& Dziedzic, H. (1974). A comparison of seven strains of Lactobacillus casei var. rhamnosus in relation to their use in the microbiological assay of serum folate. Journal of Applied Bacteriology 37, 373-389.

TENNANT, G. B. \& WITHEY, J. L. (1972). An assessment of work simplified procedures for the microbiological assay of serum vitamin $\mathrm{B}_{12}$ and serum folate. Medical Laboratory Technology 29, 171-181.

Toennies, G., Frank, H. G. \& Gallant, D. L. (1953). On the folic acid activity of human blood. Journal of Biological Chemistry 200, 23-30.

WaXman, S. (1975). Folate binding proteins. British Journal of Haematology 29, 23-29.

WhItrenbury, R. (1964). Hydrogen peroxide formation and catalase activity in the lactic acid bacteria. Journal of General Microbiology 35, I3-26.

Wood, R. C. \& Hitchings, G. H. (1959). A study of the uptake and degradation of folic acid, citrovorum factor, aminopterin and pyrimethamine by bacteria. Journal of Biological Chemistry 234, 2381-2385. 